\title{
The Strategic Context of the UAE's Nuclear Project: A Model for the Region?
}

\author{
Ali Oguz Dirioz and Benjamin A. Reimold
}

\begin{abstract}
Mr. Dirioz and Mr. Reimold are a PhD candidate and research assistant, respectively, at Bilkent University in Ankara, Turkey.
\end{abstract}

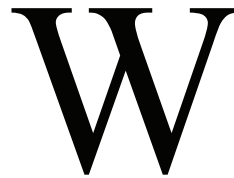

hen the government of the United Arab Emirates (UAE) issued a policy statement in April $2008^{1}$ indicating that the country was seriously considering developing a civilian nuclear-power program, it set the region and the world speculating as to the possible motivations behind such a move at that time. Since that date, the UAE has aggressively forged ahead, signing bilateral agreements with nuclear-supplier countries while increasing cooperation with the International Atomic Energy Agency (IAEA) in support of its bid to add nuclear power to its national energy portfolio. Most recently, the UAE has actually broken ground on its first and second reactors, in 2012 and 2013. At a time when the nuclear industry's "renaissance" has slowed or even faltered ${ }^{2}$ as a result of the 2011 Fukushima Daiichi accident, the global dynamics of the industry seemed to have little effect on the bold and confident pace of the UAE's nuclear plans. Worldwide, the future looks dimmer for nuclear than it did a few short years ago: Germany has pursued a policy of early decommissioning of its nuclear-power capacity; ${ }^{3}$ the Netherlands has adopted a "wait and see" attitude with respect to new nuclear plants; ${ }^{4}$ and new plants already under construction in China, France and Finland have experienced delays and cost overruns. ${ }^{5}$ Even in the face of these signs of a slowdown in the industry, however, the UAE continues to press ahead in its pursuit of nuclear power. Yet why should an oil-rich country like the UAE pursue a civilian nuclear power program, especially at a time when the future of nuclear-power around the world is uncertain?

\section{THE UAE AND NUCLEAR ENERGY}

A member of the IAEA since 1976, the UAE first entered the nuclear nonproliferation regime in 1995 with its signature of the Nuclear Nonproliferation Treaty (NPT). ${ }^{6}$ A safeguards agreement with the IAEA was signed in 2002 and entered into force in 2003. ${ }^{7}$ Three years later, in 2006, the Gulf Cooperation Council (GCC) commissioned a feasibility study on nuclearenergy development in the region. ${ }^{8}$ The UAE began its own domestic inquiries,

* The authors would like to thank Bilkent Prof. Nur Bilge Criss for her detailed initial review, as well as the faculty and 2013 cohort of the University of Florida Warrington College of Business, Post Doctoral Bridge Program, for initial feedback. 
and an important step was taken in 2009 with the successful negotiation of a " 123 Agreement" with the United States. ${ }^{9}$ This technology-transfer agreement opened the door to UAE collaboration with U.S. companies and sent a signal to other countries that the UAE was serious about proliferation concerns. The UAE followed this with the signing of an Additional Protocol with the IAEA in 2009, which entered into force the next year. ${ }^{10}$

As recommended by the IAEA, the UAE established the Federal Authority for Nuclear Regulation (FANR) in September 2009 as the governmental body responsible for the regulation and licensing of nuclear energy in the country. ${ }^{11} \mathrm{~A}$ few months later, in December 2009, the Emirates Nuclear Energy Corporation (ENEC) was established as the national nuclear operator by decree of the UAE president, Sheikh Khalifa Bin Zayed Al Nahyan. ${ }^{12}$ The ENEC was tasked with opening a bidding process for the construction of nuclear power plants in the country, assisted by a nine-member international advisory board chaired by former IAEA director Hans Blix. ${ }^{13}$

The appointment of Blix was a confidence-building measure in pursuit of transparency and public relations to assure the international community that the program is indeed for peaceful purposes only. Through incorporating the advice of experts and formally renouncing its right to reprocessing and enrichment, the UAE government has been praised for setting the "Gold Standard" for nonproliferation agreements. ${ }^{14}$

After announcing their interest in bidding for the UAE nuclear-power contract, nine companies and consortiums were pared down to a short list of three serious bids in 2009: a French consortium consisting of AREVA, Suez and Total; GE-
Hitachi; and a consortium led by the Korea Electric Power Corporation (KEPCO). ${ }^{15}$ Desiring to purchase a single reactor type, the UAE selected KEPCO's APR-1400 (based on Westinghouse's System 80+ design) over AREVA's EPR and GEHitachi's ABWR; it signed a deal for four reactors at a total $\$ 20.4$ billion. ${ }^{16}$ Financing was provided largely by the largest Emirate, Abu Dhabi. The UAE-KEPCO deal follows previous agreements signed by the UAE for the construction of conventional power plants and desalination facilities the deal specifies a 60/40 ownership split and contractor-based approach, as opposed to developing an autonomous indigenous nuclear industry. ${ }^{17}$

Construction on the first reactor, Barakah I, began in July 2012, and on Barakah II in 2013. According to the World Nuclear Association, Barakah I is scheduled to start up in 2017, with one additional reactor scheduled to come on line every year until 2020 for a total of four APR-1400 units. With the common GCC electricity grid and energy market in place since $2011,{ }^{18}$ the UAE looks to profit by selling excess capacity to its neighbors.

The worldwide nuclear industry relies heavily on experience and best practices learned over decades of operation and regulation. ${ }^{19}$ Given the high stakes involved, the safe and secure operation of a nuclear power plant must take precedence over efficiency and profitability in operation. The unique safety concerns associated with nuclear energy require a sophisticated institutional approach to ensure compliance with the highest operations standards. Even though there would arguably be environmental risks and safety concerns associated with a nuclear power plant, the decision to continue with such an investment stems from multidimensional calculations to 
counterbalance geopolitical, economic and other regional security dynamics.

Like most of the countries in its region, the UAE is rich in fossil fuels, which have produced both immense prosperity for its citizens and a lax attitude towards energy efficiency. In the UAE, this has been compounded by strong economic growth and a sudden population growth spurt, resulting in a massive increase in the demand for electricity. Cultivating a domestic source of electricity generation would not only help alleviate the increase in local consumption; the surplus could also be sold to neighboring countries. Both strengthening domestic supply sources and selling excess to neighbors reflect the complex interdependent relationship the GCC countries have with one another. Also, the same paradigm shows how the power plant in the UAE may be understood as a form of "soft power," proclaiming itself as an example of how to conduct a transparent civilian nuclear program with proper political oversight (particularly to Iran).

\section{COMPLEX INTERDEPENDENCY}

Foreign economic relations and trade are cornerstones of complex interdependency. In a globalized world, regional organizations such as the GCC create multilevel regional cooperation that tends to lead members to develop deeper ties with one another through both formal and informal channels. Trade proves to be a powerful force for increasing cooperation as boundaries to conducting international business are gradually eliminated through the building of trust. This increasing interdependency among nations is viewed as a potential alternative to pursuing strategic competition over natural resources.

In seeking to describe this phenomenon in international relations, Robert Keo- hane and Joseph Nye identify three main characteristics of interdependency. First, interdependency is characterized by societies relating to each other through "multiple channels" with an emphasis on informal and nongovernmental bonds. Second, interdependent states' relations with each other are increasingly characterized by an "absence of hierarchy among issues," where interstate relations are not restricted simply to high politics, but include businesses, multinational corporations, NGOs, etc. Finally, as states become more interdependent, Kohane and Nye argue that this relegates military force to a minor role as states grow to trust each other in specific issue areas. In its place, states prefer to use something Nye terms "soft power": seeking non-military means of rhetorically or strategically coopting other states. ${ }^{20}$

Given the importance of soft power in a world where countries have complex and interdependent relationships with one another, policy makers are often concerned for their sources and degrees of sensitivities and vulnerabilities in foreign economic relations. ${ }^{21}$ For instance, although it is a small country, the UAE today contributes 1.7 percent to world natural-gas production, while at the same time consuming a massive 2 percent of the world's total natural-gas usage. ${ }^{22}$ In order to satisfy its growing thirst for natural gas, the UAE has been forced to become a net importer of gas, even as it sits on some of the world's largest reserves. Understandably, Emirati policy makers perceive this as a strategic vulnerability and have been working to ameliorate this dependency on its neighbors for energy supply.

Why would the UAE, an important oil and natural-gas supplier, want to develop nuclear energy? We argue that Emirati nuclear ambitions can be under- 
stood through both economic and political lenses. Economically, the UAE's rapidly growing electricity consumption needs new sources of electricity supply. Politically, it is to send a message to regional actors who also aspire to develop a nuclear program without transparency. In order to avoid the threat of blockage to the strategic chokepoint of the Hormuz Strait, the UAE is also building pipelines across its territories in another effort to minimize an identified strategic vulnerability. Energy security should not merely be seen as a "resource war, ${ }^{, 23}$ but a concept in and of itself for a policy aimed at mitigating risks to security and economic infrastructure. The case of foreign assistance for building domestic electricity supply through nuclear power plants is an example of such complexity.

According to the IEA, energy security refers to the uninterrupted availability of energy sources at an affordable price. ${ }^{24}$ The IEA further emphasizes to its member countries the need to improve energy security by promoting diversity, efficiency and flexibility within the energy sectors. However, the IEA focuses mostly on supply security, while the concept of energy security might change depending on the country. C. K. Ebinger suggests that the meaning of energy security will most likely vary, depending on the viewpoint of the observer. ${ }^{25}$ One can infer that while a country like China would be concerned about security of resources and their supplies, energy producers such as the OPEC countries and Russia would be more concerned about the availability of stable markets where they could sell such resources.

The case of the UAE is particularly worth examining in that respect. It is an OPEC member state, but has in recent years started to face some of the challenges common to importing countries as it became a net importer of natural gas, due to its rapid population growth and use of natural gas as the primary source of electricity generation. Thus, for its general energy security, the UAE needs to adopt a multidimensional approach since it would need to be concerned mostly with security of transport through the Strait of Hormuz, and also with supply security of natural-gas imports.

Mitigation of geopolitical risks associated with the Strait of Hormuz would be the top priority of the UAE. The crude-oil pipeline project to Fujairah is strategically important in circumventing the chokepoint. Politically, the risk of increasing dependency on imported (mostly Qatari and Saudi) natural gas is also a growing risk factor that the UAE needs to deal with. The nuclear plant currently being built at Barakah plays an important role in providing diversification and an alternative source for electricity. With regard to the Iranian nuclear program, the UAE's program may be seen as a form of soft power by setting an example to the region for the process of obtaining civilian nuclear energy. It is important to highlight that renouncing uranium enrichment is a unilateral act enshrined in the 123 Agreement with the United States and not an international legal obligation based on 
TABLE 1. Population Increase in the UAE, 2005-1026

\begin{tabular}{lcccccc}
\hline Year & $\mathbf{2 0 0 5}$ & $\mathbf{2 0 0 6}$ & $\mathbf{2 0 0 7}$ & $\mathbf{2 0 0 8}$ & $\mathbf{2 0 0 9}$ & $\mathbf{2 0 1 0}$ \\
\hline $\begin{array}{l}\text { Population } \\
\text { (millions) }\end{array}$ & 4.11 & 5.01 & 6.22 & 8.07 & 8.20 & 8.26 \\
$\begin{array}{l}\text { Population Density } \\
\left.\text { (people } / \mathrm{km}^{2}\right)\end{array}$ & 58 & 71 & 88 & 114 & 115 & 116
\end{tabular}

the codes and rules of the IAEA. However, a sovereign country forgoing such a right sets an example for practicality and is not necessarily prescriptive as the ideal model, since the IAEA emphasis is on the transparency and accountability of the enrichment process. Finally, reducing the export of its fossil resource for electricity generation would be important for regional balances, not only vis à vis policy towards Iran, but also in terms of the UAE's bargaining power within GCC politics. Ultimately, in the case of the UAE's energy security, Emirati policy can be understood as the product of a multidimensional strategy to reduce external dependencies and address internal vulnerabilities.

\section{ECONOMIC DIMENSIONS}

Pressure to make new investments for electricity generation in the UAE comes from the rapid increase in the country's electricity consumption. This rise was triggered by a growing economy that attracted a larger population (mostly non-Emiratis) to settle in the UAE, which in turn had led to a doubling of the population since 2005. This demand increase also includes a greater need for desalination, an energyintensive process concerning the needs for water, transportation and other infrastructure. The significant increase in both population and population density is illustrated in Table 1.

FIGURE 1. Increase in Net Electricity Consumption in the $\mathrm{UAE}^{27}$

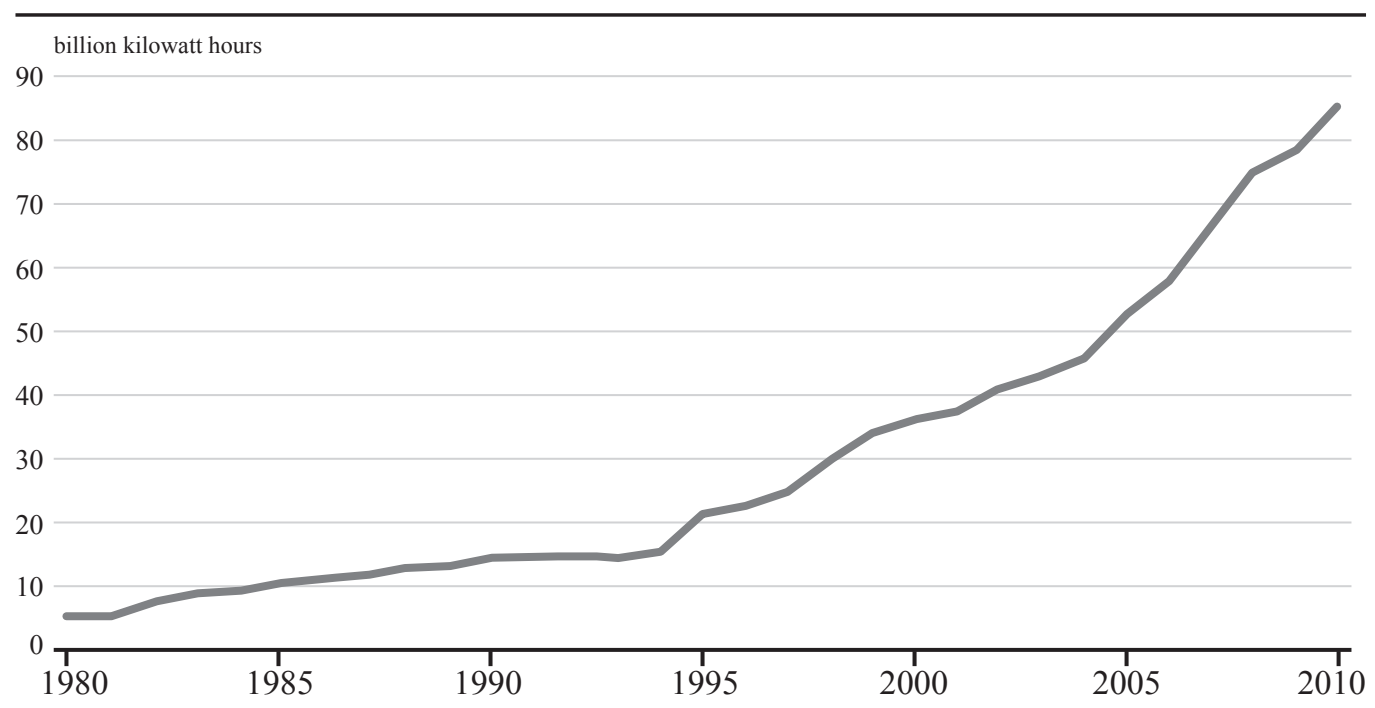

Source: U.S. Energy Information Administration 
Middle East Policy, Vol. XXI, No. 3, Fall 2014

TABLE 2. Energy Consumption, Production, and Imports of the UAE, 1971-2008 ${ }^{28}$

\begin{tabular}{|c|c|c|c|c|c|c|c|c|c|c|c|}
\hline \multirow[b]{2}{*}{$\begin{array}{l}\text { Energy } \\
\text { Consumption* }\end{array}$} & \multirow[b]{2}{*}{1971} & \multirow[b]{2}{*}{1980} & \multirow[b]{2}{*}{1990} & \multirow[b]{2}{*}{2000} & \multirow[b]{2}{*}{2004} & \multirow[b]{2}{*}{2005} & \multirow[b]{2}{*}{2006} & \multirow[b]{2}{*}{2007} & \multirow[b]{2}{*}{2008} & \multicolumn{2}{|c|}{$\begin{array}{l}\text { Average Annual } \\
\text { Growth Rate (\%) }\end{array}$} \\
\hline & & & & & & & & & & $\begin{array}{r}1971- \\
2000\end{array}$ & $\begin{array}{r}2004- \\
2008\end{array}$ \\
\hline Total & 0.04 & 0.23 & 0.66 & 1.04 & 1.10 & 1.10 & 1.10 & 1.36 & 1.42 & $11.23 \%$ & $6.52 \%$ \\
\hline Solids & 0.00 & 0.00 & 0.00 & 0.00 & 0.00 & 0.00 & 0.00 & 0.00 & 0.00 & $0.00 \%$ & $0.00 \%$ \\
\hline Liquids & 0.01 & 0.12 & 0.24 & 0.28 & 0.33 & 0.35 & 0.36 & 0.38 & 0.46 & $11.48 \%$ & $8.42 \%$ \\
\hline Gases & 0.03 & 0.08 & 0.37 & 0.62 & 0.60 & 0.56 & 0.04 & 0.73 & 0.72 & $10.44 \%$ & $5.67 \%$ \\
\hline $\begin{array}{r}\text { Primary } \\
\text { Electricity }\end{array}$ & 0.00 & 0.02 & 0.05 & 0.13 & 0.17 & 0.19 & 0.21 & 0.24 & 0.25 & $16.78 \%$ & $9.40 \%$ \\
\hline
\end{tabular}

\begin{tabular}{|c|c|c|c|c|c|c|c|c|c|c|c|}
\hline $\begin{array}{l}\text { Energy } \\
\text { Production }\end{array}$ & & & & & & & & & & & \\
\hline Total & 2.21 & 3.78 & 4.61 & 6.38 & 7.06 & 7.12 & 7.60 & 7.57 & 7.56 & $3.66 \%$ & $1.70 \%$ \\
\hline Solids & 0.00 & 0.00 & 0.00 & 0.00 & 0.00 & 0.00 & 0.00 & 0.00 & 0.00 & $0.00 \%$ & $0.00 \%$ \\
\hline Liquids & 2.18 & 3.51 & 3.91 & 4.98 & 5.25 & 5.30 & 5.70 & 5.61 & 5.80 & $2.85 \%$ & $2.48 \%$ \\
\hline Gases & 0.03 & 0.27 & 0.70 & 1.40 & 1.81 & 1.82 & 1.90 & 1.96 & 1.76 & $13.25 \%$ & $-0.61 \%$ \\
\hline $\begin{array}{r}\text { Primary } \\
\text { Electricity }\end{array}$ & 0.00 & 0.00 & 0.00 & 0.00 & 0.00 & 0.00 & 0.00 & 0.00 & 0.00 & $0.00 \%$ & $0.00 \%$ \\
\hline
\end{tabular}

\begin{tabular}{l|rrrrrrrrr|rr}
$\begin{array}{l}\text { Net Energy } \\
\text { Imports }\end{array}$ & \multicolumn{10}{|c|}{} & \\
\hline Total & -2.17 & -3.39 & -3.40 & -4.44 & -4.50 & -4.46 & -4.79 & -4.45 & -4.31 & $-2.34 \%$ & $1.10 \%$ \\
$\quad$ Solids & 0.00 & 0.00 & 0.00 & 0.00 & 0.00 & 0.00 & 0.00 & 0.00 & 0.00 & $0.00 \%$ & $0.00 \%$ \\
$\quad$ Liquids & -2.17 & -3.30 & -3.28 & -4.19 & -3.97 & -3.93 & -4.25 & -4.07 & -4.56 & $-2.15 \%$ & $3.52 \%$ \\
$\quad$ Gases & 0.00 & -0.09 & -0.12 & -0.25 & -0.53 & -0.53 & -0.54 & -0.38 & 0.25 & $-\mathbf{- 7 . 5 0 \%}$ & $\mathbf{5 6 . 8 3 \%}$
\end{tabular}

*All energy values are in Exajoules $\left(10^{18} \mathrm{~J}\right)$

One can see that both the actual population (from 4.1 million to 8.2 million) and the population density (from 58 to 116) in the UAE have doubled in a mere five years, 2005-10. This created a huge increase in the demand for electricity (see Figure 1).

By contrast, the investments aimed at increasing the output of electricity generated have remained constant during 2005-10. This is reflected in a heavy increase in the import of natural gas, a fact that is illustrated by Table 2 .
Additionally, annual electricity demand from 2007 onwards was estimated to grow at an annual rate of 9 percent. The UAE has been heavily investing in renewable-energy technologies, most notably the Masdar Initiative near Abu-Dhabi, which almost exclusively focuses on renewable energy forms, including solar, and hosts the headquarters of the International Renewable Energy Agency. ${ }^{29}$ Still, it is estimated that only 6-7 percent of the national demand could be met by renewables 
in even the most advantageous scenarios..$^{30}$

With such growing populations and economies, emerging countries such as the UAE face pressure to quickly find remedies for the growing gap between energy supply and demand. And although the UAE is a member of the Organization of Petroleum Exporting Countries (OPEC), it depends on the export of oil and natural gas in order to substantially fund the entire nation. Thus, the more subsidized oil and electricity generated from natural gas are consumed internally, the fewer resources would be available for exports, meaning fewer revenues from the primary income source.

To highlight the growing concerns since 2008, and directly because of electricity generated by natural gas, the UAE has become a net gas importer (see Figure 2).

The UAE's electricity consumption in 2010 was estimated at 85.2 billion kilowatt hours $(\mathrm{kWh}), 8.5$ percent higher than in the previous year. ${ }^{32}$ Energy efficiency would also be an important solution in addressing the growing electricity consumption rate in the UAE. In that regard, since much of the rise in electricity consumption is linked to the rise in population in urban areas, the issue of household electricity consumption rates and efficiency also become important matters to consider for future research.

Hence, there is on one hand the pressure of population growth - not mostly from births but from migration, as a consequence of the need for labor and services in a rapidly growing economy. In addition, there is also a growth in consumption per capita as cities expand. The use of electricity in more densely populated urban settings also causes the consumption of electricity to increase tremendously as citizens seek higher standards of living. Thus, this shift from net exporter to net importer of natural gas has accompanied the rapid growth in the economy of the UAE. This, of course, puts increased pressure on the government to develop new investments to address demand. In the long run, there would be a need to both increase energy efficiency and

FIGURE 2. Abrupt Shift in UAE Net Natural Gas Exports ${ }^{31}$

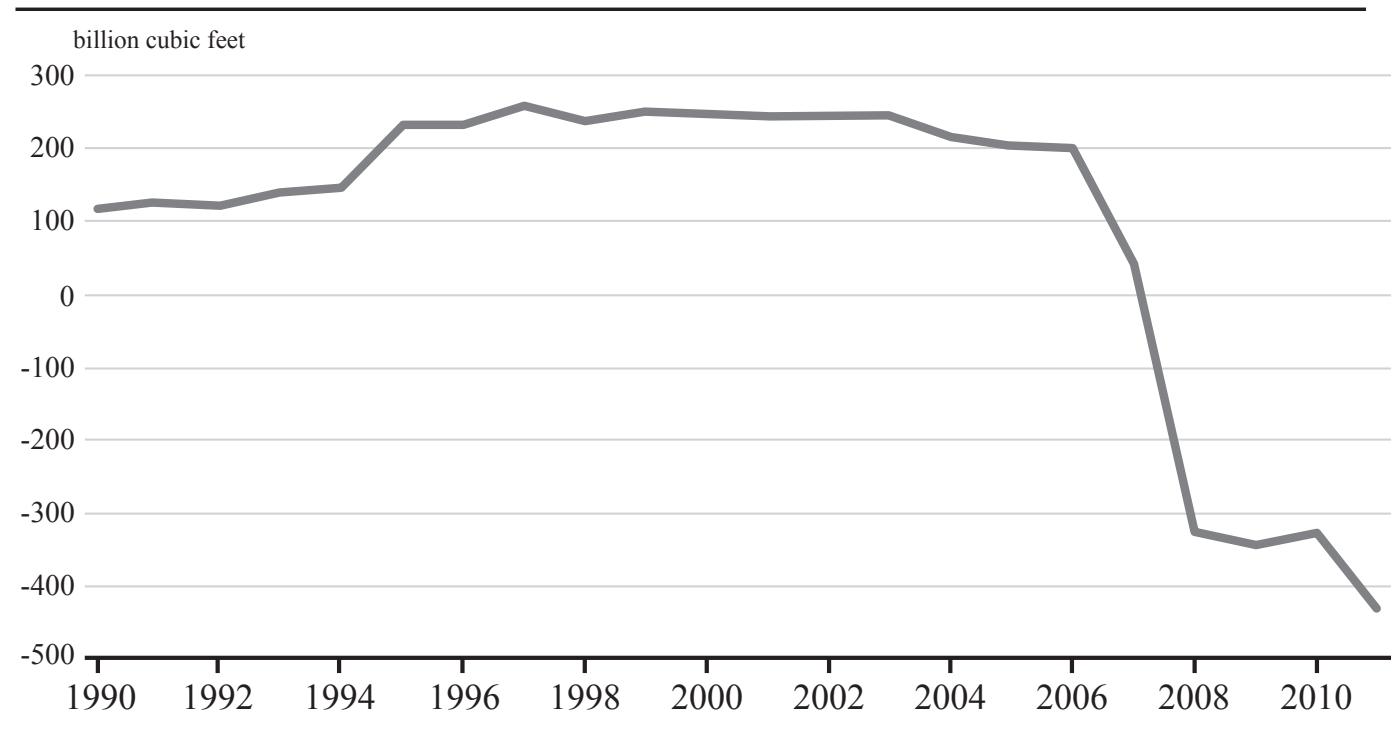

Source: U.S. Energy Information Administration 
reduce the subsidies that currently discourage advances in efficiency.

\section{GEOPOLITICAL DIMENSIONS}

Though the UAE is rich in energy resources, it could not efficiently cope with the sudden population growth consuming so much electricity, mostly generated from natural gas. The UAE has some 6.1 trillion cubic meters

of proven natural-gas reserves, roughly 3.3 percent of the world total. Its production in 2013 was around 56 bil-

Policy makers have chosen to hold its strategic reserves for future use or export. By using nuclear energy to provide baseload power, the UAE can cope with its growing demand and reduce its dependency on external sources of gas. slow or halt tanker traffic. The second is to develop more refineries and LNG terminals in Fujairah, not just for export but also reduce transport time and insurance costs by mitigating risk.

Another important aspect of risk mitigation from the UAE standpoint concerns the complex interdependent relationship among the GCC countries. The narrow lion cubic meters, corresponding to about 1.7 percent of the world production that year. ${ }^{33}$ At the same time, the UAE is now a net importer of natural gas, choosing to fill its energy deficit with imports rather than ramp up domestic production. This suggests that policy makers have chosen to hold its strategic reserves for future use or export. By using nuclear energy to provide baseload power, the UAE can cope with its growing demand and reduce its dependency on external sources of gas.

Due to its location on the Persian Gulf, the UAE is highly dependent on the Strait of Hormuz for the export of energy resources. The UAE risk-mitigation strategy to reduce dependency on this geostrategic chokepoint consists of two key components. First, by completing a pipeline for crude oil to the port of Fujairah located on the Gulf of Oman, the UAE can export crude to the world via the Indian Ocean. This eliminates the risks associated with dependency on the Strait, such as tanker accidents or political conflicts that could
Fujairah, aims to reduce its "vulnerability." The UAE depends significantly on the Strait, but it can mitigate a portion of the risk by developing alternatives for local electrical supply and hydrocarbon exports and re-exports.

In contrast, given the current political situation, Qatar would be more vulnerable to a slowdown or halt of tanker traffic at the Strait of Hormuz. Considering the current sensitive relationship between Qatar and Saudi Arabia, the UAE and Bahrain, Qatar would be more motivated to cultivate close relations with Saudi Arabia and the UAE; the former is the only country with which it shares a border, and the latter is one of its largest LNG consumers. The UAE, by reducing (though not eliminating) its dependency on Qatari natural gas for electricity generation, could use a portion of it to replace its own strategic gas resources or to re-export gas in times of crises.

This situation has perhaps been one of the important reasons for the UAE, 
Saudi Arabia and Bahrain to take the harsh measure of withdrawing their ambassadors from Qatar back in March 2014 over differences of opinion regarding the developments in Egypt. ${ }^{34}$ Furthermore, Qatar's decision to not implement reciprocity and hence not to withdraw its own ambassador has been interpreted as a gesture of appeasement, and subsequent declarations from meetings of the GCC show signs of a renormalization of relations among these states. The ambassador-withdrawal episode demonstrated the importance of relations between GCC countries and their relative dependency on the Strait of Hormuz with respect to each other. With other options besides the strait to export their oil and natural gas, Saudi Arabia and the UAE would remain sensitive but less vulnerable than Qatar to the problems of the Strait of Hormuz. The withdrawal of ambassadors could also be understood as a form of soft power ${ }^{35}$ exercised by Saudi Arabia and the UAE to coerce Qatar to show more solidarity with the other Arab dynasties.

Finally, as a political and security issue, the existence of a nuclear power plant, even if it is for civilian use, would send a political message to the other Arab and non-Arab countries of the Middle East in terms of best practices in the areas of transparency and security. The UAE attaches great importance to this issue as a matter of national prestige, to solidify its national image as a regional commercial hub and center of stability.

\section{SECURITY AND SAFEGUARDS}

In its pursuit of a civilian nuclear-power program, the UAE has been praised for its efforts aimed at assuring the international community that the program is solely for peaceful purposes. By taking the initiative to enter into many voluntary nonprolifera- tion commitments and guarantees, the UAE government has been praised for setting the "Gold Standard" for nonproliferation agreements. ${ }^{36}$ The IAEA and the nonproliferation community commonly evaluate civilian nuclear-power programs on the basis of three broad technical areas (the " 3 Ss"): safety, security and safeguards. ${ }^{37}$ These three areas are closely linked; institutional progress to improve security — increasing physical protection measures, for instance - has positive implications for facility safety and accounting for all the nuclear material on site. Achieving success in safety, security and safeguards requires a rigorous and robust institutional structure, where ties between the operator and regulating agency are limited and safety and security are not compromised in the effort to keep the nuclear plant operating.

The IAEA therefore works with states' domestic institutions in order to strengthen organizational practices, legislation and regulatory oversight in these three technical areas. The UAE is no exception; it has been working closely with the IAEA to deepen its ties of cooperation since its decision to pursue a nuclear-power program. A key step in the UAE's relationship with the IAEA came in December 2011, when the country signed a Country Profile Framework (CPF) with the agency. ${ }^{38}$ The CPF forms the inter-institutional basis for technical cooperation between the UAE and the IAEA through setting a detailed roadmap for development needs and the agency's support for national institutions. The CPF was followed by the signing of an Integrated Work Plan (IWP) in June 2013, ${ }^{39}$ a major step towards deeper institutional cooperation. The IWP specifies cooperation on technical projects intended to support the UAE's development of sound national institutions and nuclear infrastructure ac- 
cording to international best practices. ${ }^{40}$

Complying with the IAEA, the UAE established the Federal Authority for Nuclear Regulation (FANR) and the Emirates Nuclear Energy Corporation (ENEC), which serves as the national nuclear operator. ENEC was tasked with opening a bidding process for the construction of nuclear power plants in the country, assisted by a nine-member international advisory board chaired by former IAEA director Hans Blix. ${ }^{41}$ The international advisory board (IAB), by publishing semi-annual reports, provides more information to the international community about transparency, nonproliferation, safety and security of the civilian nuclear projects. Furthermore, other institutions were established both for transparency and capacity building. For instance, the Gulf Nuclear Energy Infrastructure Institute (GNEII) was established in 2011 as a Khalifa University institution. There is also a UAE Nuclear Energy Scholarships Program initiative, as a demonstration of the government of $\mathrm{Abu}$ Dhabi's commitment to developing human capital for the long-term viability of the nuclear power plants.

These confidence-building public campaigns for greater transparency and nonproliferation activities are precisely tailored for the international community in an attempt to improve the UAE's image. The UAE has not always had a positive relationship with the nonproliferation regime — the notorious proliferation network established by Pakistani nuclear scientist A.Q. Khan used Dubai as an important transit hub in the effort to acquire dual-use technologies. Through local front companies established by taking advantage of the UAE's lax regulation, the A.Q. Khan network was able to use Dubai to hide the sources and destinations of the supplies it was seeking to acquire. Because of the complicated UAE federal system, each of the Emirates had a different set of customs laws, and interagency cooperation among the Emirates was virtually nil. The A.Q. Khan network exploited this lack of effective export controls in its efforts to acquire key fuel-cycle technologies.

When the A.Q. Khan network was exposed in early 2004, the role of the UAE - and Dubai as a strategic transit point — fell under the microscope of policy makers in the West. ${ }^{42}$ Pressure began to build for the UAE to improve its export laws, and in September 2007 the first federal export and trade-control law was passed. This law provided for coordination among all the Emirates in the area of export and control of dual-use technologies at the federal level, covering all import, export and transit of dual-use items in Emirati territory, including its Free Trade Zones. ${ }^{43}$ Still, it took almost two years for the commission tasked with overseeing the new law to meet for the first time, ${ }^{44}$ suggesting that enforcement of the law may be lagging behind its strength on paper. The speed with which the UAE pursued its nuclear program has left some observers apprehensive that its institutions may not be able to keep up with the pace of construction.

\section{MANAGING CHALLENGES}

How did the UAE successfully overcome these challenges to its nuclear ambitions, and how do the tactics it used shed light on its strategic position? The UAE was able to allay the concerns of potential suppliers through careful negotiation and extending unilateral guarantees. Specifically, in bilateral negotiations, Emirati policy makers successfully pitted potential suppliers against each other. France was 
the first country to be approached about the possibility of a technology-transfer agreement, at the same time that France was attempting to negotiate a naval base for French forces in Emirati territory. France was approached first because of its demonstrated willingness to sign nuclear-assistance deals with a wide range of states. Second, an agreement with France would become leverage in negotiations with the United States. With the French deal in hand and the naval-base negotiations ongoing, the UAE turned to Washington for a 123 Agreement for nuclear-technology transfer. The United States was worried about the implications that failure to sign a 123 Agreement would have on its strategic partnership with the UAE. Washington's concerns were alleviated through the UAE's willingness to formalize its unilateral public declarations not to seek the full nuclear-fuel cycle. A key condition of the U.S.-UAE 123 Agreement formalizes the UAE's pledge not to acquire enrichment or reprocessing capabilities, prompting some to label the UAE's approach the Gold Standard of how to pursue a peaceful nuclear-power program. ${ }^{45}$

After achieving legitimacy and leverage from the successfully negotiated assistance agreement with France, Emirati policy makers consulted with a wide range of experts from many members of the Nuclear Suppliers Group (NSG), the key international body tasked with controlling the transfer of dual-use technologies. By inviting participation from many different sources within the NSG during the formative stage of its nuclear program, the UAE ensured that those who were consulted would approve and advocate for the resulting policy direction taken by the UAE. This negotiation also contributed to a competitive bidding process. By generating excitement in the right channels about the seriousness of their intentions, Emirati negotiators first secured the necessary legal frameworks to ensure that multiple countries and consortiums would be able to offer competitive bids. By playing off potential suppliers against each other, both for acquiring technology-transfer agreements and for the actual bidding process, UAE policy makers ensured they were able to make a secure and economical choice for a nuclear vendor.

\section{CONCLUSION}

In this paper we have placed the UAE's nuclear-power program in its strategic context, specifically with respect to the economic and geopolitical factors the country faces. Acquiring nuclear energy helps address these identified vulnerabilities and sensitivities. In addition, Emirati policy makers have sought to portray their country as an example for the region of how to acquire foreign nuclear assistance in a correct and transparent manner. What makes sense for the UAE, given its unique situation, however, may not prove to be easily replicable by other aspiring countries, whose economic and geopolitical situations may dictate further political and financial concessions in order to acquire nuclear plants of their own. Overall, the nuclear-power program of the UAE is an excellent example of sound economic and political decision making, but the jury remains out concerning Emirati claims of their program's representing a model for the region. 
Middle East Policy, Vol. XXI, No. 3, Fall 2014

${ }^{1}$ UAE, Policy of the United Arab Emirates on the Evaluation and Potential Development of Peaceful Nuclear Energy (Abu Dhabi, 2008).

2 P.L. Joskow, and J.E. Parsons, The Future of Nuclear Power After Fukushima, February, 2012 (Cambridge, 2012).

${ }^{3}$ World Nuclear Association, Nuclear Power in Germany, 2014, http://www.world-nuclear.org/info/countryprofiles/countries-g-n/germany/.

${ }^{4}$ World Nuclear Association, Nuclear Power in the Netherlands, 2013, http://www.world-nuclear.org/info/ country-profiles/countries-g-n/germany/.

${ }^{5}$ J. Kanter "In Finland, Nuclear Renaissance Runs Into Trouble," New York Times, May 29, 2009: 5-7.

${ }^{6}$ UNODA, Treaty on the Non-Proliferation of Nuclear Weapons (2014), http://disarmament.un.org/treaties/t/ npt.

${ }^{7}$ IAEA, "Country Details: United Arab Emirates," (2014), http://ola.iaea.org/ola/FactSheets/CountryDetails. asp?country=AE.

${ }^{8}$ NTI, “Country Profiles: United Arab Emirates"” (2013). http://www.nti.org/country-profiles/united-arabemirates/. (June 17, 2014).

${ }^{9}$ FANR, "History of FANR," (2013). http://www.fanr.gov.ae/En/AboutFANR/Pages/History-of-FANR.aspx. (June 24, 2014).

${ }^{10}$ UNODA, Treaty on the Non-Proliferation of Nuclear Weapons.

${ }^{11}$ FANR, "History of FANR," (2013). http://www.fanr.gov.ae/En/AboutFANR/Pages/History-of-FANR.aspx. (June 24, 2014).

${ }^{12}$ ENEC, “About Us,” (2013). http://www.enec.gov.ae/about-us/history/.

${ }^{13}$ IAB, “About Us,” (2013). http://www.uaeiab.ae/about.php.

${ }^{14}$ NTI, “Country Profiles: United Arab Emirates"” (2013). http:/www.nti.org/country-profiles/united-arabemirates/. (June 17, 2014).

${ }^{15}$ World Nuclear Association, "Nuclear Power in the United Arab Emirates," (2014). http://www.worldnuclear.org/info/Country-Profiles/Countries-T-Z/United-Arab-Emirates/.

${ }^{16}$ Ibid.

${ }^{17}$ Ibid.

${ }^{18}$ G. Duncan, “UAE Links to GCC Electricity Grid.” National, April 21, 2011. Available at: http://www. thenational.ae/business/economy/uae-links-to-gcc-electricity-grid.

${ }^{19}$ R.K. Lester, and M.J. McCabe, "The Effect of Industrial Structure on Learning by Doing in Nuclear Power Plant Operation," RAND Journal of Economics 24, no. 3 (1993): 418-438.

${ }^{20}$ R.O. Keohane, and J.S. Nye, Power and Interdependence, Third Edition, (New York: Longman, 2001): 20-25.

${ }^{21}$ J.S. Nye, Understanding International Conflicts: An Introduction to Theory and History. Seventh Ed. (London: Longman, 2009).

${ }^{22}$ BP. Statistical Review of World Energy: 2014, Available at: bp.com/statisticalreview.

${ }^{23}$ P. Le Billion, "The Geopolitical Economy of 'Resource Wars,", Geopolitics 9, no. 1 (2004): 1-28.

${ }^{24}$ IEA. "Energy Security," (2014). http://www.iea.org/topics/energysecurity/.

${ }^{25}$ C.K. Ebinger, "The Meaning of Energy Security Depends on Who You Are," (Brookings Institute, 2011). http:/www.brookings.edu/research/opinions/2011/10/10-energy-security-ebinger.

${ }^{26}$ UAE National Bureau of Statistics, Analytical Report on Economic and Social Dimensions in the United Arab Emirates 2009, (Abu Dhabi, 2010) http://www.uaestatistics.gov.ae/ReportPDF/Analytical report on economic and social dimensions in the united arab emirates.pdf.

${ }^{27}$ EIA, "United Arab Emirates," (2013). http://www.eia.gov/countries/country-data.cfm?fips=TC\#elec.

${ }^{28}$ IAEA, UAE Country Nuclear Power Profile (Vienna, 2012), http:/www-pub.iaea.org/MTCD/Publications/ PDF/CNPP2012_CD/countryprofiles/UnitedArabEmirates/UnitedArabEmirates.htm.

${ }^{29}$ Masdar, “About Masdar” (2014), http://www.masdar.ae/en/\#masdar/all.

${ }^{30}$ P. Le Billion, "The Geopolitical Economy of 'Resource Wars,", Geopolitics 9, no. 1 (2004): 1-28.

${ }^{31}$ BP Statistical Review of World Energy: 2014, available at: bp.com/statisticalreview

${ }^{32}$ EIA, Analysis Brief-UAE (2013), available at: http://www.eia.gov/countries/analysisbriefs/UAE/uae.pd.

${ }^{33}$ BP Statistical Review of World Energy: 2014, available at: bp.com/statisticalreview

${ }^{34}$ After the Egyptian military's overthrow of the democratically elected Muslim Brotherhood president 
Muhammed Morsi in July 2013, the military command led by General Sisi took control of the government. While most GCC countries were supportive of Sisi, Qatar sided with Morsi and the Muslim Brotherhood, and the Al-Jazeera media network (incidentally based in Qatar) has been very critical of the military coup in Egypt. Similar differences over the developments in Syria also created an apparent foreign policy rift between Qatar and the rest of the GCC.

${ }^{35}$ J.S. Nye, "Get Smart: Combining Hard and Soft Power," Foreign Affairs 88, no. 4 (2009): 160-63.

${ }^{36}$ NTI, "Country Profiles: United Arab Emirates" (2013) http://www.nti.org/country-profiles/united-arabemirates/.

${ }^{37}$ C. Stoiber, A. Cherf, W. Tonhauser, and M. Carmona, Handbook on Nuclear Law: Implementing Legislation (Vienna: IAEA, 2010).

${ }^{38}$ UAE, "UAE Signs Cooperation Framework with IAEA,” (2011), http://www.uae-mission.ae/mission/iaea/ news/2011/12/20/178.

${ }^{39}$ IAEA, "United Arab Emirates and IAEA Sign an Integrated Work Plan (IWP) to Support the Implementation of the National Nuclear Power Programme" (2013), http://www.iaea.org/technicalcooperation/Home/ Highlights-Archive/Archive-2013/06062013-UAE-IWP.html.

${ }^{40}$ P. Le Billion, "The Geopolitical Economy of 'Resource Wars," Geopolitics 9, no. 1 (2004): 1-28.

${ }^{41}$ IAB, “About Us," (2013). http://www.uaeiab.ae/about.php.

${ }^{42}$ D.E. Sanger, "The Khan Network," Conference on South Asia and the Nuclear Future (Stanford: Stanford Institute for International Studies, 2004).

${ }^{43}$ B.R. Early, "Acquiring Foreign Nuclear Assistance in the Middle East," Nonproliferation Review 17, no. 2 (2010): 259-280.

${ }^{44}$ Ibid.

${ }^{45}$ NTI, "Country Profiles: United Arab Emirates" (2013). http://www.nti.org/country-profiles/united-arabemirates/. (June 17, 2014). 